\title{
Sociological Indicators of Ethical Attitude toward Ethnic Humor: An Empirical Study on Persian Jokes
}

\author{
E. F. Haghish ${ }^{1}$, Arash Heydari ${ }^{2}$, Robert Biegler ${ }^{3}$, Gerit Pfuhl ${ }^{3} \&$ Ali Teymoori $^{4}$ \\ ${ }^{1}$ Center of Child Language, University of Southern Denmark \& Clinical Epidemiology, University Medical \\ Center Freiburg, Germany \\ ${ }^{2}$ Department of Sociology, Allameh University, Iran \\ ${ }^{3}$ Department of Psychology, Norwegian University of Science and Technology, Norway \\ ${ }^{4}$ School of Psychology, University of Queensland, Australia \\ Correspondence: E. F. Haghish, University of Southern Denmark \& Clinical Epidemiology, University Medical \\ Center Freiburg, 79104 Freiburg, Germany. E-mail: haghish@imbi.uni-freiburg.de
}

Received: June 27, 2012 Accepted: July 17, 2012 Online Published: October 18, 2012

doi:10.5539/ass.v8n13p9 URL: http://dx.doi.org/10.5539/ass.v8n13p9

\begin{abstract}
People's ethical attitude toward ethnic humor (EATEH) is not well-investigated. The present article explores the relation of gender, anomie, socioeconomic status, ethnocentrism, and national identity to ethical attitude toward ethnic humor. 500 high school students were surveyed from 10 high schools of Ahvaz, Iran. Findings revealed that attitudes toward jokes are significantly related to the dimensions of ethnocentrism, anomie, socioeconomic status, national identity, and gender. A significant proportion of the EATEH's variance was predicted by socioeconomic status and anomie, whereas ethnocentrism was still significant but played only a minor role. Further, on average men show prejudice more openly than women. Findings show that ethical attitude of individuals toward ethnic humor have been rooted and influenced by sociological factors most notably their social context and feeling of anomie.
\end{abstract}

Keywords: ethnic jokes, anomie, socioeconomic status, ethnocentrism, national identity, Iran

\section{Introduction}

Compared to psychologists, sociologists have had little interest in studying unserious social discourse such as joke and humor (Mulkay, 1988). As a result, less attention has been devoted to the sociology of ethnic jokes (Best, 2007; Davies, 1998). Since the 1980s, however, there has been increased interest in studying the origin and function of ethnic jokes (Martin, 1998). Sociological research on ethnic jokes has centered on sources of ethnic humor, which are "ethnocentrism, in-group adulation, out-group resentment, prejudice, and intolerance of the life-styles of others (Apte, 1985)." In addition, sociological studies have shown interest in studying the functions of ethnic jokes in multiethnic society (see below). Yet, people's perception of the rightness and wrongness of this type of humor has been neglected. Similarly, sociological factors that might influence people's ethical attitude toward ethnic and racist jokes - i.e. factors that encourage or discourage people to tell and enjoy ethnic jokes- have not been well-investigated. In the current study, we aim to address questions such as how do people ethically judge ethnic or racist jokes? Do they have any notion that telling such jokes might be ethically wrong? What sociological factor can predict people's ethical attitude toward ethnic humor?

To address these questions we surveyed Iranians. Iran is home to 74 million people who are culturally, linguistically, ethnically, and religiously diverse. The core ethnic group is Persian with over 51 per cent of Iran's population, as compared with Turks, Lurs, Kurds, Baluchis, Arabs, Christians, Jews, Zoroastrians, and other minorities who constitute less than half of population of the country (Hassan, 2007). In broad terms, Iranian ethnic rivalries have been less discussed during the recent decades but explicit ethnic prejudice has remained evident in this country (Amirahmadi, 1987; Asgharzadeh, 2007; Van Gorder, 2010). Research has shown that globalization and feelings of discrimination have isolated peripheral ethnic groups in Iran leading them to develop stronger ethnic identities and be more pessimistic toward the out-groups (Fokoohi \& Amoosi, 2009; Koutlaki, 2010; Moghadas Jafari, Sheikhavandi, \& Sharifpour, 2008; Rabani, yazdkhasti, Hajiani, \& Mirzaei, 2009; Shaffer, 2002). Such diversity of religions, customs, and ethnic identities have been pointed out by 
sociological studies as an ample background for ethnic humor, which is a popular type of joke in Iran (Apte, 1985, 1987; Davies, 1982, 1990; Mik-Meyer, 2007).

Haghish et al., (Submitted) developed a new questionnaire for measuring ethical attitude toward ethnic humor (EATEH). They found that people have different ethical perspectives toward ethnic jokes. Some people perceive ethnic jokes as racist expressions, whereas others might call them only a nice joke. Further, they found that moral emotions such as empathy makes individuals develop criteria for distinguishing jokes that are in good or bad taste. That is in contrast to the philosophical and theoretical arguments that struggle in setting a criterion for specifying a border between good and bad taste. The current article is a follow up on that research; however, it attempts to address sociological factors that influence people's ethical attitude toward ethnic humor. More specifically, it aims to explore how social elements such as ethnocentrism, anomie, socioeconomic status, and national identity, relate to ethical attitude toward ethnic humor. We consider these factors one by one to discuss the literature and illustrate how these factors might relate to ethical attitude toward ethnic jokes.

\subsection{Ethnocentrism and Ethnic Humor}

Ethnic humor is defined as a "type of humor in which fun is made of the perceived behavior, customs, personality, or any other traits of a group or its members by virtue of their specific sociocultural identity (Apte, 1985, p. 198)." Ethnic humor in Iran, the subject of the current research, humiliates peripheral ethnic groups by naming their ethnicities or their cities. Regardless of the target (ethnicity or city), Persian ethnic jokes ascribe canny, cruel, and immoral traits and stereotypes to people of different ethnic groups and cities and humiliate them. In this regard, Asgharzadeh (2007) articulates that Persian ethnic jokes include racial insults against peripheral ethnic groups and argues that “... victims of this kind of abuse know very well that it is not just a joke (p. 148)."

Because of hateful, racist, and insulting expressions that are often found in ethnic jokes, the link between ethnic jokes and racism, prejudice, and ethnocentrism has been addressed by much research. Relating ethnic jokes to ethnocentrism, racism, prejudice, and hatred implies, according to psychodynamic theory, that these jokes carry serious hints of hatred (Best, 2007; Lowe, 1986). Sigmund Freud (1976) classified jokes into various types and focused on "tendentious jokes" that he considered to include a purpose above the "innocent humor." Linking purposeful content of tendentious jokes to repressed desires such as sexual and aggression instincts and, on the other hand, social needs such as freedom vs. authority, wealth vs. poverty, and alike, Freud illustrates the psycho-social conflicts of popular mind as the source of jokes: "The popular mind, which created these stories, and others like them, is torn by similar conflict (p. 151)." Although Freud did not specifically analyze ethnic humor in detail, his approach has been frequently used in interpreting the purpose and function of ethnic humor. Based on psychodynamic theory, ethnic humor is viewed as a defense mechanism that helps to express belief and attitudes that cannot be expressed directly (releasing suppressed energies) to a group of people. For instance, Oshima (2000) remarks that humor works out as a defense mechanism: "humor functions as a displacement of the violence and aggression which are both part of the human instinct. This applies also to the function of ethnic humor in multi-ethnic society" (p.41). Similarly, Billig (2001) argues that people may enjoy expressing hatred in racist jokes (see also Husband, 1988).

Contrary to this approach, Davies (1990) asserted that ethnic humor should not be considered as directly hostile or racist expressions. He asserts two sets of crucial boundaries for each ethnic group: 1) social and geographical boundaries that identify the members and 2) moral boundaries that explain the accepted rules among the members (Davies, 1982). In his opinion, ethnic humor determines the socio-cultural boundaries and reduces the ambiguity or the threat by attacking these boundaries: "Ethnic jokes police these boundaries. They mock groups who are peripheral to the central or dominant group or who are seen by them as ambiguous. They ascribe to these groups traits which the group telling the jokes does not wish to recognize among its own members (p. 383)". Davies emphasizes that there is no direct relationship between the content and purpose of the joke because jokes are first and foremost jokes. He also indicates that ethnic jokes target peripheral groups that might be hated or liked and thus, ethnic humor is not necessarily emerging from hatred.

Although there is a debate among scholars to what extent ethnic humor represents racism or hatred, it seems that there is a general agreement that ethnocentrism and prejudice are major sources of ethnic jokes (Mintz, 1996). Research also has shown that ethnocentrism and social identity are central to ethnic prejudice (Perreault \& Bourhis, 1998, 1999). Therefore, it is crucial to include this variable in studying people's attitude toward ethnic jokes.

\subsection{National Identity and Ethnic Jokes}

Identity has been well-investigated regarding prejudice and racism (Hopkins, 2001). In the realm of humor, 
identity is one of the main boundaries that ethnic jokes target. In a sense, jokes that humiliate the language, dress, habits and beliefs of an ethnic group, are denigrating their identity (Davies, 1982; Vucetic, 2004). Specifically, jokes that are told regarding stereotypes of other countries, such as jokes that Scandinavians tell about each other, highlight commonly accepted national stereotypes. Gundelach (2000) points out that narratives denigrating national stereotypes serve to strengthen "the relevance of the nation as a social entity (114)." In his point of view, jokes are one of the commonly used forms of narratives that the Scandinavians use when they recount what is typically Danish, Norwegian or Swedish.

What we intend to examine in the current study is the relation between national identity and ethical attitude toward ethnic jokes. If national stereotypes are a way groups identify others groups' life styles, identities, traits, etc., then they are more likely to believe in the stereotype of the humor (see Billig, 1995). As a result, believing in a stereotype (e.g. Jews are canny) makes one more reluctant to object to the humor because one finds it very much close to reality and reality is not something we may object to.

\subsection{Anomie}

Exploring the potential relation feelings of anomie to ethnic jokes demands in depth discussion since these two concepts have not been linked together (web of sciences yields no result). The term anomie stems from anomia, the Greek term that pertains to absence of law (Caruana, Ramaseshan, \& Ewing, 2000). In sociology, anomie has been addressed on the one hand at the micro level of analysis, underscoring individual's perception, feelings, and values toward dominant normative order (Rushing, 1971), and on the other hand at the macro level of analysis, centering on impersonal and structural characteristics of the society such as normlessness. Here we briefly review the central theories of anomie and discuss how anomie might relate to ethnic humor in a multi-ethnic society.

The social-structural theories of anomie (i.e. macro level) were developed by Durkheim and Merton underlining moral groundlessness and separation of means and goals as sources of anomie (Agnew, 1980; see also Kapsis, 1978). Durkheim $(1951,1984)$ describes anomie as a state of normlessness in which society's major values break down or become invalid to people. Durkheim asserts that this pathological status reflects individuals' sense of moral groundlessness that happens when a norm is challenged and people cannot find an appropriate substitute: "At the very moment when traditional rules have lost their authority, the richer prize offered these appetites stimulates them and makes them more exigent and impatient of control" (Durkheim, 1984; p. 214). Anomie is assumed to occur under rapid social changes such as economic recession or splendor, war, and fast population growth that make people feel frustrated and unsatisfied regarding their desires ${ }^{1}$ (Konty, 2005). Similar to Durkheim, Merton (1968) focuses on social-structural dimensions of anomie, but emphasizes the gap between culturally reinforced goals and institutional means as the cause of anomie. These two theories agree that society's characteristics can produce undesirable emotions such as anger, fear, and frustration and damages socio-moral norms that leads to deviant behavior, hedonism, and crime (Konty, 2005), though they disagree on some points. First and foremost, while Durkheim underlines invalid norms as the main source of anomie, Merton illustrates anomie as a characteristic of a maladaptive society and lists five types of adaptation, which are conformity, innovation, ritualism, retreatism, and rebellion (for more details see Caruana et al., 2000). Moreover, unlike Durkheim who states that anomie occurs periodically over time but uniformly throughout the society, Merton claims that anomie can occur as a permanent feature of a society (Bernard, 1995, p. 86). Merton names two essential elements for social norms, which are culturally defined goals and institutionalized (legitimated) means that actualize the goals (Merton, 1968). When there is excessive cultural emphasis on some goals but available opportunities are poor, people do not reach those goals (or satisfy the valued needs) and as a result the society becomes anomic.

Since the 1950s, more attention has been paid to micro-level anomie, centering on psychological facets of anomie and the way anomie influences individuals' mutual interaction (Menard, 1995; Orru, 1987). In contrast to macro-level theories that center on the societal-structural sources of anomie (Konty, 2005), Maclver could throw some light on the psychological aspects of anomie. Maclver (1950, quoted from Orru, 1987) describes anomie as the collapse of individual's sense of attachment to society and asserts three situations that cause detachment: 1) culture clash that occurs when a system of values becomes invalid for individuals; 2) capitalistic competitiveness; and 3) rapid social change. Srole (1956) elaborated Maclver's theory by focusing on individual-level anomie that he named anomia. According to Srole, anomia pertains to "self-to-other distance" or "self-to-other alienation (Srole, 1956, p. 711)." Srole distinguished five dimensions of psychological sense of anomie to explain the degree of an individual's integration with the society, which are as follow: (1) The belief that the society's leaders are ignoring individuals' needs; (2) Perceiving social order as being unpredictable; (3) The notion that people are retrogressing from their goals; (4) The feeling that life is meaningless; (5) The perception that the 
individual's personal relationships are not predictable or supportive.

Discussing how feelings of anomie might relate to ethnic humor is important since, to our knowledge, these two concepts have not been linked to each other. At the micro-level, anomie creates an imbalance between individual's self-interest and other people's interest. Such a psychological perception of anomie i.e. "imbalance between social and self-interests (Konty, 2005, p. 110)," causes normlessness, a feeling of being abandoned, frustration, a variety of conflicts, and selfishness (emphasize one's own interests) that consequently break down individuals' attachment to their society and isolate them from others (Cao, 2007; Farnworth \& Leiber, 1989; Konty, 2005; Menard, 1995; Winslow, 1968). At the macro scale, anomie weakens the society's moral boundary and makes individuals feel lost because of lack of valid norms and values.

Such a normless society provides a background for hatred or distrust that shows itself in different ways. For instance, it biases the individual towards a hostile perception of his world in which "other" become enemies who try to take advantage of him (Fischer, 1973; Kapsis, 1978). For example, anomie has been linked to crime and deviant behavior (see Cao, 2007; Durkheim, 1951; Farnworth \& Leiber, 1989; Konty, 2005) and also to ethnocentrism and prejudice (McDill, 1961; Roberts \& Rokeach, 1956; Scheepers, Felling, \& Peters, 1992; Srole, 1956).

Therefore, on the one hand, feelings of anomie might encourage ethnic jokes to reduce interpersonal and intergroup ambiguities. As Davies (1982) remarks: "[ethnic jokes] express the problems and anxieties caused by the conflicting norms and values inevitably found in large societies dominated by anomic impersonal institutions such as the market place and bureaucracy (p. 383)". On the other hand, feelings of anomie bias individuals to be selfish, hateful, isolated, and insecure, and consequently they are more likely to have prejudiced and racist thoughts, which are linked to ethnic humor (McDill, 1961; Roberts \& Rokeach, 1956; Scheepers et al., 1992; Srole, 1956). However, very little attention has been paid to anomie as a potential source of ethnic humor.

\subsection{Socioeconomic Status}

Characterizing the way socioeconomic status influences individuals and families' social being has been one of the main concerns of sociological studies (Dos Santos, 1970; Ekehammar, Sidanius, \& Nilsson, 1987). The concept of "social class" or "socioeconomic status" was developed to include the process of ranking individual's and families' social position by wealth, occupation, education, and a variety of other factors (Martineau, 1958). This concept is chiefly focused on individuals' interaction in their social context (Bodenhausen, Macrae, \& Garst, 1998; Macrae \& Bodenhausen, 2001). Interaction of an individual with a specific social category shapes individuals' perception of themselves and others' social status and also generates stereotypes that work as expectancies for the social environment (Weeks \& Lupfer, 2004). For example, members of low socioeconomic class are expected to have lower income, lower education and knowledge, lower participation in political organizations, and more isolated occupations and economic insecurity (Lipset, 1959).

Socioeconomic status influences racial prejudice (Jones, 1997; Weeks \& Lupfer, 2004). This phenomenon is described as social class prejudice, which pertains to "negative attitude toward one's social class out-group (Weeks \& Lupfer, 2004, p. 977)." Further, middle and upper-class people prefer to interact with their equals and judge the working class with disdain (Giles, Gatlin, \& Cataldo, 1976; Laumann \& Guttman, 1966). Moreover, ethnic minorities are more likely to be found in the lower social classes than upper classes (Herring, 1989; Jones, 1997; Pettigrew, 1981, 1985; Runciman, 1972; Triandis \& Triandis, 1960; Weeks \& Lupfer, 2004). Therefore, such class separation between ethnic groups might strengthen inter-group conflicts and consequently, reinforce prejudice (Wilson, 1980). In studying inter-group or racial prejudice, it is necessary to consider socioeconomic status as well as ethnicity (see also Jones, 1997).

\section{Rationale of the Study}

As noted at the outset of the article, sociological studies have ignored individuals' perception of ethnic jokes and mainly examined the social sources and functions of this type of humor. In the current study, we attempt to examine the way socio-cultural factors such as anomie, socioeconomic status, ethnocentrism, and gender differences relate to people's ethical attitudes toward ethnic jokes.

We expected to find a negative correlation between anomie and ethnocentrism with ethical attitude toward ethnic jokes, mainly because these variables make individuals care less about other people. In addition, a body of research has shown that women are less likely to express prejudice and more likely to show empathy toward others (Basow, 1992; Johnson, Brems, \& Alford-Keating, 1997; Whitley Jr, 1999). Therefore, we expected to see a higher mean for men on ethnocentrism, anomie, and attitude toward ethnic jokes. Finally, we hypothesize that socioeconomic status is positively correlated with ethical attitude toward ethnic humor, on the grounds that 
people of lower socioeconomic status have more feelings of anomie and also might be more oriented toward taking prejudicial viewpoints.

\section{Method}

\subsection{Participants and Procedure}

500 students were chosen by the cluster method of sampling from ten high schools of Ahvaz, Iran. Nine of the participants were purged from the analysis due to incomplete answers. Participants consisted of 283 males and 194 females and 14 students did not mention their gender. They ranged in age from 14 to 18 with mean age of 16.14 and standard deviation .99. The ethnic distribution of the sample was as follows: 177 Fars, 172 Lors, 2 Kurds, 103 Arabs, 8 Turks, and 29 did not mention their ethnicity. The ethnic diversity of the sample shows that the sample is not homogenous and only to some extent represents the ethnic diversities of the Iranian society. The subjects participated voluntarily and were assured anonymity.

\subsection{Instrument}

Participants completed seven different scales: (1) Ethnocentrism scale, (2) anomie scale, (3) subjective socioeconomic status scale, (4) national identity scale, and (5) attitude toward ethnic jokes.

\subsubsection{Ethical Attitude toward Ethnic Jokes (EATEH)}

We used a recently developed scale for measuring individuals' perception toward harmfulness of ethnic humor and objections and behavioral reactions toward this type of humor (Haghish et al., submitted).The ethical attitude toward ethnic humor scale includes 15 self-report items and requires subjects to provide their opinion about ethnic jokes and rate to what extent they agree or disagree with the statement on a 7 point Likert-type format (i.e. from "strongly agree" to "strongly disagree"). The scale makes no value judgment about "moral maturity" or "racist attitude" of people. Instead, it collects self-perceived information about different joke-related issues that can determine one's ethical attitude toward this type of humor. This instrument has shown to have criterion validity by its significant relationships with empathy, authoritarianism, and self-efficacy. It also has predictive validity since a significant amount of its variance was explained by perspective taking, empathic feeling and experiences, empathic perspective taking, empathic awareness, acceptance of other cultures, personal distress, authoritarianism, and self-efficacy. In addition, it has a good construct validity as the items obtained satisfactory factor loading (.50 to .85) and also confirmatory factor analysis confirmed the one factor model of EATEH; moreover, Average Variance Extracted (AVE: as one indicator of convergent validity) of 0.52 demonstrated adequate and satisfactory convergent validity of the scale. For reliability of the scale, an alpha coefficient of 0.94 and also Composite Reliability of 0.944 were obtained indicating the scale is very reliable (Haghish et al., submitted).

\subsubsection{Anomie}

To measure anomie, the nine-point revised instrument of Srole (1956) was translated into Persian. Since the 1960s, this scale has been used in sociological studies for measuring anomie (McDill, 1961; Mizruchi, 1960; Scheepers et al., 1992). To maximize the variance, the original scale was elaborated by replacing yes/no responses with a Likert scale, as found in Caruana, et al. (2000). All the scale's items were described at either end by 1 (Strongly Agree) and 5 (Strongly Disagree). The scoring was applied such that the higher the sum of the scale, the greater are the individuals' feelings of anomie. To determine the validity of the translated questionnaire, 40 participants were surveyed and an Alpha coefficient of 0.66 was obtained. The scale is shown to have predictive validity through its significant association with authoritarianism and socioeconomic status (Heydari et al., 2012).

\subsubsection{Subjective Socioeconomic Status}

The participants also were asked to report their socioeconomic status. That included a subjective perception of social class. Research has shown that compared to objective socioeconomic status, subjective perception of social class is a better predictor of psychological health and well-being of individuals (Adler, Epel, Castellazzo, \& Ickovics, 2000; Cohen et al., 2008; Mirowsky \& Ross, 2000). Interestingly, the correlation coefficient of objective and subjective socioeconomic status has been found to differ from one ethnicity to another, ranging from 0.2 to 0.5 (Ekehammar et al., 1987; Ostrove, Adler, Kuppermann, \& Washington, 2000). Subjective socioeconomic status was measured by 6-item questionnaire constructed by Nabavi, Hosseinzade, \& Hosseini (2009). The scale is a subjective measure of socioeconomic status using 6 positively keyed items in a five-point answer format ( 1 = "Very Valueless"; 2 = "Valueless"; 3 = "Somewhat Valuable"; 4 = "Valuable"; 5 = Very Valuable") and has alpha coefficient of 0.77. 


\subsubsection{Ethnocentrism}

The scale used in the present article for measuring ethnocentrism was developed by Navah et al. (2010) to measure ethnocentrism within the sociocultural context of Iran. The scale consists of two five-item subscales, which measure unfavorable attitude toward out-groups (out-group ethnocentrism) and favorable attitude toward in-group (in-group ethnocentrism). The predictive validity of the scale was obtained through its significant association with authoritarianism, $\mathrm{r}=0.51, \mathrm{p}<.01$, and socioeconomic status, $\mathrm{r}=0.14, \mathrm{p}<.05$ (Navah et al., 2010). The scale requires the respondents to rate the answer the items in five-point Likert format, ranging from 5- "strongly agree" to 1- "strongly disagree." The scales have each a Cronbach's alpha of .85.

\subsubsection{National Identity}

Since there was no reliable measurement of national identity in Iran, we developed a new scale for measuring this variable. Several items were generated and handed to 10 social psychology experts in Shahid Chamran University, Iran. The lecturers were asked to evaluate the face validity of the items, considering socio-cultural context of Iran. After implementing the offered corrections, six items were selected that seemed to be most relevant. A Likert scale was used for the measurement ranging from 1- strongly disagree to 5-strongly agree. To examine the validity and reliability of the scale, 180 individuals were surveyed using the scale. Factor analysis suggests that the scale would be at its best when extracting only one factor and the following six items (see table 1). The scale has Alpha coefficient of .84 .

Table 1. Items of national identity scale

\begin{tabular}{lc}
\hline Alpha 0.89 & Factor loading \\
\hline I am proud of being Iranian & .65 \\
In case of invasion, I will fight for my country to defend it & .718 \\
When national sport teams of my country succeed I feel honored. & .815 \\
I wish I was born in another country* & .725 \\
I do my best to help developing my country. & .751 \\
Sometimes I feel ashamed that I am an Iranian* & .81 \\
I don't care how rich and historical the civilization of Iran is* & .824 \\
\hline
\end{tabular}

* Items with reversed scoring

\section{Results}

Descriptive statistics (Means and standard deviation) for age, anomie, socioeconomic status, ethnocentrism, National Identity, and EATEH are given in Table 2. Sense of anomie, ethnocentrism, and national identity are relatively high among the participants, whereas EATEH is relatively low (i.e. average of positive attitude toward ethnic jokes) in the sample. In addition, subjects perceived their own social class as being between middle and upper class ( $\mathrm{M}=15.86, \mathrm{SD}=4.62)$.

Table 2. Descriptive statistics of all measured scales

\begin{tabular}{lcccc}
\hline & M & SD & Min & Max \\
\hline Age & 16.14 & .99 & 14 & 18 \\
Socioeconomic status & 15.86 & 4.62 & 5 & 25 \\
Anomie & 29.96 & 7.37 & 9 & 45 \\
Ethical attitude toward ethnic jokes & 41.59 & 18.20 & 15 & 105 \\
In-group ethnocentrism & 18.38 & 5.08 & 5 & 25 \\
Out-group ethnocentrism & 14.62 & 5.33 & 5 & 25 \\
National identity & 19.95 & 7.26 & 7 & 35 \\
\hline
\end{tabular}

T-tests were carried out to explore whether there are any gender differences in the ethical attitude toward ethnic jokes, SES, anomie, two dimensions of ethnocentrism, and national identity of the participants. Levene's Test for Equality of Variances test was significant in EATEH, anomie, and national identity. Equal variances were not assumed in the differences of gender in these constructs and subscales. There, the T-test was modified to correct for unequal variances. The results revealed that male score significantly higher than females on EATEH, $\mathrm{t}(470.66)$ $=4.06, \mathrm{p}<.0001$ (male: $\mathrm{M}=44.15, \mathrm{SD}=20.72 \&$ female: $\mathrm{M}=37.94, \mathrm{SD}=12.66$ ). In addition, there were 
significant gender differences in in-group oriented ethnocentrism $(\mathrm{t}(476)=2.15, \mathrm{p}<.05)$, out-group oriented ethnocentrism $(\mathrm{t}(476)=3.1, \mathrm{p}<.01)$, and national identity $(\mathrm{t}(443.09)=-1.98, \mathrm{p}<.05)$. Males scored higher on ethnocentrism scale indicating that men are more likely to be ethnocentric, whereas females obtained higher scores on national identity.

Next, the Pearson correlation was used to explore the association between the measured variables, as summarized in Table 3. Based on Table 3, SES had a negative significant relationship with EATEH $(\mathrm{r}=-.50, \mathrm{p}$ $<.01)$, anomie $(\mathrm{r}=-.49, \mathrm{p}<.01)$, in-group ethnocentrism $(\mathrm{r}=-.35, \mathrm{p}<.01)$, and out-group ethnocentrism $(\mathrm{r}=$ $-.31, \mathrm{p}<.01)$. Anomie, in-group ethnocentrism, and out-group ethnocentrism had positive significant correlation with EATEH $(\mathrm{r}=.49, \mathrm{r}=.32, \mathrm{r}=.35, \mathrm{p}<.01$, respectively). The higher the scores in anomie and ethnocentrism the more positive an attitude would be required to tell ethnic jokes. In contrast, national identity had positive significant correlation with EATEH $(r=-.34, \mathrm{p}<.01)$ implying that whenever the national identity is strong, one is more likely to have a negative attitude toward ethnic jokes.

Table 3. Pearson correlation coefficients between EATEH, SES, anomie, in-group ethnocentrism, out-group ethnocentrism, and national identity

\begin{tabular}{lccccc}
\hline Variables & EATEH & SES & Anomie & In-group ethnocentrism & Out-group ethnocentrism \\
\hline 1. EATEH & 1 & - & - & - & \\
2. SES & $-.50^{*}$ & - & - & - & \\
3. Anomie & $.49^{*}$ & $-.49^{*}$ & - & - & \\
4. In-group ethnocentrism & $.32^{*}$ & $-.35^{*}$ & $.40^{*}$ & - & \\
5.Out-group ethnocentrism & $.35^{*}$ & $-.31^{*}$ & $.38^{*}$ & $.59^{*}$ & -.29 \\
6. National identity & $.34^{*}$ & $.28^{*}$ & $-.27^{*}$ & -.22 & \\
\hline
\end{tabular}

$* \mathrm{P}<0.01$

Finally, we looked to what extent SES, anomie, ethnocentrism, and national identity account for variance in ethical attitude toward ethnic jokes. To do so, standardized regression analysis was used and EATEH was entered as a dependent variable, while SES, anomie, in-group ethnocentrism, out-group ethnocentrism, and national identity were entered as independent variables (Table 4). The full model was significant, $\mathrm{R}^{2}=.38, \mathrm{~F}(5,482)=$ $59.05, \mathrm{p}<.0001$ in which $38 \%$ of the variance of ethical attitude toward ethnic humor was predicted by SES, anomie, ethnocentrism, and national identity variables. The combination of predictor variables has significant effect on EATEH, $\mathrm{B}=40.58, \mathrm{t}=6.89, \mathrm{p}<.0001$. In detail, $\mathrm{SES}, \mathrm{B}=-1.10, \beta=-.28, \mathrm{t}=-6.57, \mathrm{p}$ $<.0001$, anomie, $\mathrm{B}=.68, \beta=.27, \mathrm{t}=6.25, \mathrm{p}<.0001$, national identity, $\mathrm{B}=-.42, \beta=-.17, \mathrm{t}=-4.31, \mathrm{p}<.0001$, and out-group ethnocentrism $B=.34, \beta=.10, t=2.14, p<.05$ accounted for a significant variance of EATEH individually while the unique effect of in-group ethnocentrism was not significant. As it can be seen, the SES has the most significant effect on the people's ethical perception $(\beta=-.28)$ and the next significant predictor is Anomie $(\beta=.27)$.

Table 4. Multiple regression analyses, using SES, anomie, in-group ethnocentrism, out-group ethnocentrism, and national identity as predictor variables and EATEH as dependent variable

\begin{tabular}{llllll}
\hline Variable & B & SE & $\beta$ & $\mathrm{t}$ & Sig \\
\hline Constant & 40.58 & 5.89 & & 6.89 & .000 \\
SES & -1.10 & .17 & -.28 & -6.57 & .000 \\
Anomie & .68 & .11 & .27 & 6.25 & .000 \\
National identity & -.42 & .10 & -.17 & -4.31 & .000 \\
In-group ethnocentrism & .09 & .16 & .03 & .56 & .577 \\
Out-group ethnocentrism & .34 & .16 & .10 & 2.14 & .033 \\
\hline
\end{tabular}

$\mathrm{R}^{2}=.38, \mathrm{R}^{2}$ adj. $=.37, \mathrm{~F}(5,482)=59.05, \mathrm{p}<.000$

\section{Discussion}

The study attempted to explore what sociological factors make some people condemn ethnic humor and others enjoy it. The relation of a variety of sociological factors such as socioeconomic status, anomie, national identity, and ethnocentrism to ethical attitude toward ethnic jokes were examined.

The basic findings are straightforward. Substantial individual differences were found in the attitude toward ethnic humor. Since ethnic jokes are very popular in Iran, we expected to see a general positive attitude toward 
this kind of humor. Our previous research (Haghish et al.submitted) showed that those who have positive attitude toward ethnic jokes are more likely to believe in the stereotypes employed by the jokes. This indicates that ethnic jokes are not merely jokes. They include a hint of prejudice, especially for those who really find them acceptable. The significant correlation between ethnocentrism dimensions and attitude toward ethnic jokes support this assertion.

Previous research also demonstrated that men tend to express prejudiced attitudes more than women (Altemeyer, 1998; Kite \& Whitley Jr, 1998; Whitley Jr, 1998, 1999). Similarly, we found significant difference between men and women in EATEH. On average, men obtained a significantly higher score on ethical attitude toward ethnic humor than women showing that they are less critical toward ethnic jokes. The findings of this research are in concordance with a study by Lundell (1993), which indicates that men are more likely to enjoy dirty jokes than women. This can be related to Ekehammar et al., (2003) who argued that women seem to express implicit prejudice and men explicit prejudice terms. He defines implicit prejudice as misjudging a person who is described in an "ambiguous story" in an impression formation task. How about ethnic and racist jokes? Can we consider them to be implicit jokes? Is there any cultural difference in type of racist expressions across gender? Apparently, ethnic jokes are not explicit forms of racial statements and might be considered as implicit prejudice. However, more research is needed to find out how women and men differ on ethical attitude toward ethnic jokes.

According to our findings, the overall average of participants' scores on sense of anomie was relatively high. This result was expected based on the social background of $\operatorname{Iran}^{1}$ and the few relevant domestic research articles (Heydari, 2010; Heydari et al., 2012). Anomie and socioeconomic status were significantly correlated with EATEH (see also Haghish et al., submitted). Similarly, significant correlation was found between anomie and socioeconomic status. The explanation for this finding comes from the theory of anomie, which assumes that lower social classes have limited access to legitimate means and subsequently cannot fulfill their social needs and hence would be more frustrated and anomic (Bell, 1957; A. Heydari, 2010; Lee \& Clyde, 1974; Menard, 1995; Mizruchi, 1960; Rushing, 1971; Teevan, 1975). Similarly, both anomie and socioeconomic status have been considered to be related to prejudice and ethnocentrism (Giles et al., 1976; Jones, 1997; Laumann \& Guttman, 1966; Weeks \& Lupfer, 2004), which was evident also in our study.

In general, previous research has shown that socioeconomic status does not significantly relate to attitude toward ethnic jokes (Jaret, 1999; Middleton, 1959). For example, Jaret (1999) in studying attitudes of blacks and whites in US toward ethnic jokes writes that general feelings and attitudes about ethnic humor "are not simple functions of demographic or structural variables like age, sex, race, socioeconomic status, or metropolitan residence. These variables are correlated less strongly with ethnic humor sentiments than they are with other frequently researched attitudinal variables such as opinions about drug use, gun control, abortion, or prejudice (p.402)."

However, the results of our study show such assertions to some extent might be culturally dependent since in our study attitude toward ethnic humor was significantly related to a variety of sociological variables. Besides, our findings support the idea that ethnic jokes are not merely jokes that are meant to be funny and bring laughter. Instead, attitude toward ethnic jokes shows a significant association with variables that induce dogmatic attitude toward out-groups such as ethnocentrism, authoritarianism, anomie, and low socioeconomic status. In addition, the EATEH scale shows that people who have a positive attitude toward ethnic humor believe in the stereotypes of the ethnic jokes and laugh at them (Haghish et al., submitted).

Given our results, it is necessary to do more research on the relation of anomie and ethnic humor. Contrary to the ethnocentrism that causes between-group prejudice, anomie is a more general term that relates to the structure of the society rather ethnic conflict. We believe that this study opened a broader frame to the realm of jokes by discussing ethnic humor as a phenomenon that is related to the structure of the society as well as inter-group matter. We suggest further research on anomie and attitude toward ethnic jokes to find out if individual-societal conflict can contribute to ethnic humor. Of course, it would be interesting to see if similar results can be found in other cultures to compare to this set of data.

\section{References}

Adler, N. E., Epel, E. S., Castellazzo, G., \& Ickovics, J. R. (2000). Relationship of subjective and objective social status with psychological and physiological functioning: Preliminary data in healthy, White women. Health Psychology, 19(6), 586. http://dx.doi.org/10.1037/0278-6133.19.6.586

Agnew, R. S. (1980). Success and Anomie: A Study of the Effect of Goals on Anomie*. Sociological Quarterly, 21(1), 53-64. http://dx.doi.org/10.1111/j.1533-8525.1980.tb02198.x

Altemeyer, B. (1998). The other "personality". Advances in experimental social psychology, 30, 47-91. 
http://dx.doi.org/10.1016/S0065-2601(08)60382-2

Amirahmadi, H. (1987). A theory of ethnic collective movements and its application to Iran. Ethnic and Racial Studies, 10(4), 363-391. http://dx.doi.org/10.1080/01419870.1987.9993578

Apte, M. L. (1985). Humor and laughter: An anthropological approach. Cornell university press.

Apte, M. L. (1987). Ethnic humor versus" sense of humor". American Behavioral Scientist. http://dx.doi.org/10.1177/000276487030003004

Asgharzadeh, A. (2007). Iran and the challenge of diversity: Islamic fundamentalism, Aryanist racism, and democratic struggles. Palgrave Macmillan.

Basow, S. A. (1992). Gender: Stereotypes and roles. Thomson Brooks/Cole Publishing Co.

Bell, W. (1957). Anomie, social isolation, and the class structure. Sociometry, 20(2), 105-116. http://dx.doi.org/10.2307/2785636

Bernard, T. J. (1995). Merton versus Hirschi: Who is faithful to Durkheim's heritage. The legacy of anomie theory, 81-90.

Best, J. (2007). Product Review: Good Humor, Bad Taste: A Sociology of the Joke. Contemporary Sociology: A Journal of Reviews, 36(5), 456. http://dx.doi.org/10.1177/009430610703600528

Billig, M. (1995). Banal nationalism. Sage Publications Ltd.

Billig, M. (2001). Humour and hatred: The racist jokes of the Ku Klux Klan. Discourse \& Society, 12(3), 267. http://dx.doi.org/10.1177/0957926501012003001

Bodenhausen, G. V., Macrae, C. N., \& Garst, J. (1998). Stereotypes in thought and deed: Social-cognitive origins of intergroup discrimination.

Cao, L. (2007). Returning to Normality. International Journal of Offender Therapy and Comparative Criminology, 51(1), 40. http://dx.doi.org/10.1177/0306624X06294427

Caruana, A., Ramaseshan, B., \& Ewing, M. T. (2000). The effect of anomie on academic dishonesty among university students. International Journal of Educational Management, 14(1), 23-30. http://dx.doi.org/10.1108/09513540010310378

Cohen, S., Alper, C. M., Doyle, W. J., Adler, N., Treanor, J. J., \& Turner, R. B. (2008). Objective and subjective socioeconomic status and susceptibility to the common cold. Health Psychology, 27(2), 268. http://dx.doi.org/10.1037/0278-6133.27.2.268

Davies, C. (1982). Ethnic jokes, moral values and social boundaries. The British journal of sociology, 33(3), 383-403. http://dx.doi.org/10.2307/589483

Davies, C. (1990). Ethnic humor around the world: A comparative analysis. Indiana University Press.

Davies, C. (1998). Jokes and their Relation to Society. Mouton de Gruyter.

Dos Santos, T. (1970). The concept of social classes. Science \& Society, 34(2), 166-193.

Durkheim, E. (1951). Suicide: A study in sociology (G. Simpson, Trans.). NY: the Free Press. The original work first published in 1893.

Durkheim, E. (1984). The division of labor in society. NY: the free press. The original work first published in 1893.

Haghish, E. F., Biegler, R., Teymoory, A., Heydari, A., \& Pfuhl, G. (Submitted). Psychological Indicators of Ethical Attitude toward Ethnic Joke: The New Ethnic Joke Attitude Scale. Journal of Current Psychology.

Haghish, E. F., Heydari, A., Pfuhl, G., Biegler, R., \& Teymoori, A. (submitted). The Scale of Ethical Attitudetoward Ethnic Humor (EATEH): Development, Erliability, and Validity.

Ekehammar, B., Akrami, N., \& Araya, T. (2003). Gender differences in implicit prejudice. Personality and Individual Differences, 34(8), 1509-1523. http://dx.doi.org/10.1016/S0191-8869(02)00132-0

Ekehammar, B., Sidanius, J., \& Nilsson, I. (1987). Social status: Construct and external validity Source. The Journal of social psychology, 127(5), 473-481. http://dx.doi.org/10.1080/00224545.1987.9713731

Farnworth, M., \& Leiber, M. J. (1989). Strain theory revisited: Economic goals, educational means, and delinquency. American Sociological Review, 54(2), 263-274. http://dx.doi.org/10.2307/2095794

Fischer, C. S. (1973). On urban alienations and anomie: powerlessness and social isolation. American 
Sociological Review, 38(3), 311-326. http://dx.doi.org/10.2307/2094355

Fokoohi, N., \& Amoosi, M. (2009). هويت ملى و هويت قومى در كردستان ايران [national identity and ethnic identity in Kurdestan, Iran]. . [national identity and ethnic identity in Kurdestan, Iran]. Youth, Culture, and Society Research, 2, 49-75.

Freud, S. (1976). Jokes and their relation to the unconscious (1905). London: Cox \& Wyman Ltd. The original work first published in 1905.

Giles, M. W., Gatlin, D. S., \& Cataldo, E. F. (1976). Racial and class prejudice: their relative effects on protest against school desegregation. American Sociological Review, 41(2), 280-288. http://dx.doi.org/10.2307/2094474

Gundelach, P. (2000). Joking relationships and national identity in Scandinavia. Acta Sociologica, 43(2), 113.

Hassan, H. D. (2007). Iran: Ethnic and Religious Minorities.

Herring, C. (1989). Convergence, polarization, or what?: Racially based changes in attitudes and outlooks, 1964-1984. The Sociological Quarterly, 30(2), 267-281. http://dx.doi.org/10.1111/j.1533-8525.1989.tb01522.x

Heydari, A. (2010). The Role of Socioeconomic and Cultural Factors on Feeling of Anomie. Unpublished master's thesis. Master, Shahid Chamran University, Ahvaz.

Heydari, A., Teymoori, A., Nasiri, H., \& Haghish, E. F. (2012). Relationship Between Socioeconomic Status, Anomie, and Authoritarianism. e-Bangi: Journal of Social Sciences and Humanities, 7(1).

Hopkins, N. (2001). National identity: Pride and prejudice? British Journal of Social Psychology, 40(2), 183-186. http://dx.doi.org/10.1348/014466601164795

Husband, C. (1988). Racist Humor and Racist in British Television or I Laughed till you Cried. Cited by Billig, Michael (2001). Humour and hatred: The racist jokes of the Ku Klux Klan. Discourse \& Society, 12(3), 267-289. http://dx.doi.org/10.1177/0957926501012003001

Jaret, C. (1999). Attitudes of whites and blacks towards ethnic humor: A comparison. Humor, 12(4), 385-410. http://dx.doi.org/10.1515/humr.1999.12.4.385

Johnson, M. E., Brems, C., \& Alford-Keating, P. (1997). Personality correlates of homophobia. Journal of Homosexuality, 34(1), 57-69. http://dx.doi.org/10.1300/J082v34n01_05

Jones, J. M. (1997). Prejudice and racism. McGraw-Hill Humanities/Social Sciences/Languages.

Kapsis, R. E. (1978). Black ghetto diversity and anomie: A sociopolitical view. The American Journal of Sociology, 83(5), 1132-1153. http://dx.doi.org/10.1086/226677

Kite, M. E., \& Whitley Jr, B. E. (1998). Do heterosexual women and men differ in their attitudes toward homosexuality? A conceptual and methodological analysis.

Konty, M. (2005). Microanomie: the cognitive Foundations of the Relationships between ANomie and Deviance. Criminology, 43(1), 107-132. http://dx.doi.org/10.1111/j.0011-1348.2005.00004.x

Koutlaki, S. A. (2010). Among the Iranians: A Guide to Iran's Culture and Customs. London: Intercultural Press.

Laumann, E. O., \& Guttman, L. (1966). The relative associational contiguity of occupations in an urban setting. American Sociological Review, 169-178. http://dx.doi.org/10.2307/2090902

Lee, G. R., \& Clyde, R. W. (1974). Religion, socioeconomic status, and anomie. Journal for the Scientific Study of Religion, 13(1), 35-47. http://dx.doi.org/10.2307/1384799

Lipset, S. M. (1959). Democracy and working-class authoritarianism. American Sociological Review, 24(4), 482-501. http://dx.doi.org/10.2307/2089536

Lowe, J. (1986). Theories of Ethnic Humor: How to Enter, Laughing. American Quarterly, 38(3), 439-460. http://dx.doi.org/10.2307/2712676

Lundell, T. (1993). An experiential exploration of why men and women laugh. Humor-International Journal of Humor Research, 6(3), 299-318. http://dx.doi.org/10.1515/humr.1993.6.3.299

Macrae, C. N., \& Bodenhausen, G. V. (2001). Social cognition: Categorical person perception. British Journal of Psychology, 92(1), 239-255. http://dx.doi.org/10.1348/000712601162059

Martin, R. A. (1998). Approaches to the sense of humor: A historical review. The sense of humor: Explorations 
of a personality characteristic, 15-60.

Martineau, P. (1958). Social classes and spending behavior. The Journal of Marketing, 23(2), 121-130. http://dx.doi.org/10.2307/1247828

McDill, E. L. (1961). Anomie, authoritarianism, prejudice, and socioeconomic status: An attempt at clarification. Social Forces, 39(3), 239-245. http://dx.doi.org/10.2307/2573215

Menard, S. (1995). A developmental test of Mertonian anomie theory. Journal of Research in Crime and Delinquency, 32(2), 136. http://dx.doi.org/10.1177/0022427895032002002

Merton, R. K. (1968). Social theory and social structure. Free Pr.

Middleton, R. (1959). Negro and white reactions to racial humor. Sociometry, 22(2), 175-183. http://dx.doi.org/10.2307/2786021

Mik-Meyer, N. (2007). Interpersonal relations or jokes of social structure? Laughter in social work. Qualitative Social Work, 6(1), 9. http://dx.doi.org/10.1177/1473325007074163

Mintz, L. E. (1996). Humor and Ethnic Stereotypes in Vaudeville and Burlesque. MELUS, 21(4), 19-28. http://dx.doi.org/10.2307/467640

Mirowsky, J., \& Ross, C. E. (2000). Socioeconomic status and subjective life expectancy. Social Psychology Quarterly, 63(2), 133-151. http://dx.doi.org/10.2307/2695888

Mizruchi, E. H. (1960). Social structure and anomia in a small city. American Sociological Review, 25(5), 645-654. http://dx.doi.org/10.2307/2090138

Moghadas Jafari, M., Sheikhavandi, D., \& Sharifpour, H. (2008). رابطه هويت ملى و هويت قومى در بين جوانان كرد ] [the relation between national and ethnic identities among Kord youth]. National studies, 9, 97-126.

Mulkay, M. (1988). On humour: Its nature and its place in modern society. Polity Press.

Nabavi, S. A., Hosseinzade, H. A., \& Hosseini, S. H. (2009). بررسى تاثير بايكاه اجتماعى-اقتصادى و هويت قومى بر احساس امنيت اجنماعى. The effect of socioeconomic status, powerlessness, and ethnic identity on social security. [The effect of socioeconomic status, powerlessness, and ethnic identity on social security]. Daneshe Entezami, $10(2), 9-36$.

Navah, A., Heydary, A., \& Froutankia, S. (2010). بررسى اثر بايخاه اجتماعى اقتصادى و اقتناركرايى بر قومدارى Investigating the effect of socioeconomic status and authoritarianism on ethnocentrism. Iranian Journal of Human development, 16, 1-25.

Orru, M. (1987). Anomie: history and meanings. Allen \& Unwin.

Oshima, K. (2000). Ethnic jokes and social function in Hawai'i. Humor-International Journal of Humor Research, 13(1), 41-58. http://dx.doi.org/10.1515/humr.2000.13.1.41

Ostrove, J. M., Adler, N. E., Kuppermann, M., \& Washington, A. E. (2000). Objective and subjective assessments of socioeconomic status and their relationship to self-rated health in an ethnically diverse sample of pregnant women. Health Psychology, 19(6), 613. http://dx.doi.org/10.1037/0278-6133.19.6.613

Perreault, S., \& Bourhis, R. Y. (1998). Social identification, interdependence and discrimination. Group Processes \& Intergroup Relations, 1(1), 49. http://dx.doi.org/10.1177/1368430298011005

Perreault, S., \& Bourhis, R. Y. (1999). Ethnocentrism, social identification, and discrimination. Personality and Social Psychology Bulletin, 25(1), 92. http://dx.doi.org/10.1177/0146167299025001008

Pettigrew, T. F. (1981). Race and class in the 1980s: An interactive view. Daedalus, 110(2), 233-255.

Pettigrew, T. F. (1985). New Black-White patterns: how best to conceptualize them? Annual Review of Sociology, 11, 329-346. http://dx.doi.org/10.1146/annurev.so.11.080185.001553

Rabani, A., yazdkhasti, B., Hajiani, E., \& Mirzaei, H. A. (2009). [the relation of national and ethnic identities among Azeri, Kord, and Arab students of governmental universities of Iran]. National Studies, 10.

Roberts, A. H., \& Rokeach, M. (1956). Anomie, authoritarianism, and prejudice: A replication. The American Journal of Sociology, 61(4), 355-358. http://dx.doi.org/10.1086/221767

Runciman, W. (1972). Race and social stratification. Race \& Class, 13(4), 497. http://dx.doi.org/10.1177/030639687201300406

Rushing, W. A. (1971). Class, Culture, and" Social Structure and Anomie". The American Journal of Sociology, 
76(5), 857-872. http://dx.doi.org/10.1086/225002

Scheepers, P., Felling, A., \& Peters, J. (1992). Anomie, authoritarianism and ethnocentrism: Update of a classic theme and an empirical test. Politics \& the Individual.

Shaffer, B. (2002). Borders and brethren: Iran and the challenge of Azerbaijani identity. The MIT Press.

Srole, L. (1956). Social integration and certain corollaries: An exploratory study. American Sociological Review, 21(6), 709-716. http://dx.doi.org/10.2307/2088422

Teevan, J. J. (1975). On measuring anomia: Suggested modification of the Srole Scale. The Pacific Sociological Review, 18(2), 159-170. http://dx.doi.org/10.2307/1388630

Triandis, H. C., \& Triandis, L. M. (1960). Race, social class, religion, and nationality as determinants of social distance. The Journal of Abnormal and Social Psychology, 61(1), 110. http://dx.doi.org/10.1037/h0041734

Van Gorder, A. C. (2010). Christianity in Persia and the Status of Non-muslims in Iran. Lexington Books.

Vucetic, S. (2004). Identity is a Joking Matter: Intergroup Humor in Bosnia. Spacesofidentity. net, 4(1).

Weeks, M., \& Lupfer, M. B. (2004). Complicating race: The relationship between prejudice, race, and social class categorizations. Personality and Social Psychology Bulletin, 30(8), 972. http://dx.doi.org/10.1177/0146167204264751

Whitley Jr, B. E. (1998). Sex differences in heterosexuals' attitudes toward homosexuals: It depends upon what you ask.

Whitley Jr, B. E. (1999). Right-wing authoritarianism, social dominance orientation, and prejudice. Journal of Personality and Social Psychology, 77(1), 126-134. http://dx.doi.org/10.1037/0022-3514.77.1.126

Wilson, W. J. (1980). The declining significance of race: Blacks and changing American institutions. University of Chicago Press, Chicago.

Winslow, R. W. (1968). Status Management in the Adolescent Social System: A Reformulation of Merton's Anomie Theory. The British journal of sociology, 19(2), 143-159. http://dx.doi.org/10.2307/588691

\section{Notes}

Note 1. During the last four decades, Iran has gone through rapid socioeconomic transitions such as revolution (1979), 8 years of continuous war against Iraq (22 September 1980 to 20 August 1988) very fast population growth (Roughly 30 million at 1979- about 70 million at 2009), and recession. Such changes are considered unfavorable for every society, which might result in anomic status. 